\title{
A FRAMEWORK FOR DIGITAL TRANSFORMATION AND BUSINESS MODEL INNOVATION
}

\author{
Chanté van Tonder ${ }^{*}$ \\ Chris Schachtebeck ${ }^{* *}$ \\ Cecile Nieuwenhuizen ${ }^{* * *}$ \\ Bart Bossink $k^{* * * *}$
}

Received: 21. 8. 2020

Preliminary communication

Accepted: 28. 10. 2020

UDC 005.591:005.21

DOI: https://doi.org/10.30924/mjcmi.25.2.6

\begin{abstract}
With the advent of the Fourth Industrial Revolution, businesses are adapting to the use of digitalisation which requires the digital transformation of their existing business models. However, there is limited empirical research on this phenomenon. The purpose of this study is twofold: (i) to develop a framework for businesses to digitally transform their business models and (ii) to examine literature in order to identify and analyse the constructs underlying the three concepts of Digitalisation, Digital Transformation and Business Model Innovation. The study is qualitative in nature and is based on a narrative review.

the first two constructs require digital capabilities and a digital strategy. The third construct requires digital transformation in the realm of customercentricity, resources, processes and profit. A set of propositions was formulated and the commonalities were mapped. Based upon this map, a conceptual framework was developed. The findings will assist in the development of future instruments that can guide businesses to digitally transform existing business model elements. This study aims to fill the gap on how business model innovation should be pursued through digital transformation by developing a conceptual framework.
\end{abstract} Relevant articles were identified by using international bibliographic databases and scrutinised using thematic analysis. The findings reveal that

Keywords: digitalisation, digital transformation, business model innovation

\section{INTRODUCTION}

The emergence of digital technologies has radically transformed businesses. Digital technologies have become the

driver of the Fourth Industrial Revolution, largely through digital business transformation (Nwaiwu, 2018). Digital technologies have not only modified traditional business

* Chanté van Tonder (Corresponding author), University of Johannesburg, Department of Business Management, Johannesburg, South Africa, Phone: +27 83276 6082, Email: chantevt@uj.ac.za, ORCID: https://orcid. org/0000-0002-1155-416X

** Chris Schachtebeck, Senior Lecturer, University of Johannesburg, Department of Business Management, Johannesburg, South Africa, Phone: +27(11) 559 3623, Email: cschachtebeck@uj.ac.za, ORCID: https://orcid. org/0000-0002-9133-2590

*** Cecile Nieuwenhuizen, Professor, University of Johannesburg, Department of Business Management, Johannesburg, South Africa, Phone: +27(11) 5594369, Email: cecilen@uj.ac.za, ORCID: https://orcid.org/0000-0003-4925-3212

${ }^{* * * *}$ Bart Bossink, Professor, Vrije Universiteit, Department of Science, Business and Innovation, Amsterdam, Netherlands, Phone: +31 (20) 5989242, Email: b.a.g.bossink@vu.nl, ORCID: https://orcid.org/0000-0001-9809-5121 


\section{Journal of Contemporary Management Issues}

structures but have also redefined what it means to be a customer and how individuals live and interact with one another in the Fourth Industrial Revolution (Berman et al., 2016). Kavadias et al., (2016) disagree with the notion that digital technologies are exclusively responsible for business transformation; they do however concede that these technologies play an important role in transformation. Westerman (2017:1) concurs with this more nuanced view, stating that technology doesn't provide value to a business, technology's value comes from doing business differently because technology makes it possible.

Business Model Innovation (BMI) is a concept that has been researched for several decades. In recent years, digitalisation and digital transformation have emerged in the Industry 4.0 sphere, yet it is important to emphasise that these two concepts are distinctly different. Regardless of this, the problem is that core characteristics, components, or elements of these concepts are inconsistent. Regarding business models, some authors (Latifi \& Bouwman, 2017) offer an arbitrary list of components that are unrelated to the agreed elements of a business model. With regards to digitalisation and digital transformation, a variety of elements relating to these two concepts have been cited, such as strategy, digital capabilities, managerial competence, customers, information and infrastructure (Li et al., 2017; Orji, 2019). Nevertheless, many other components have been included by various authors such as digital processes, digital investment, value chain, value shop, value network and analytical capabilities (North et al., 2019).

There is no universally accepted, robust conceptual framework that can assist businesses, practitioners and academics to understand the constructs of digitalisation, digital transformation and BMI (Mhlungu et al., 2019). The MIT Sloan Management Review who conducted a global study in 2014 (Kane et al., 2015) agrees with this notion. Fitzgerald et al., (2013) regard transformation as the use of digital technologies that would enable a business to improve the customer experience, develop new suitable business models and to streamline business processes. Westerman et al., (2011) define digital transformation as the use of technology to improve business performance. Verhoef (2019) claims that businesses that pursue digital transformation, also implement BMI. Hess et al., (2016) agrees with this notion, stating that one of the consequences of digital transformation is the creation of a new business model. In contrast, Kane et al., (2015) states that digital transformation does not stem from the use of technology, but rather depends on the digital strategy that is implemented by business leaders. Westerman et al., (2011) defines digitalisation as the changes that occur within a business due to the increased usage of digital technologies, leading to improved business performance.

As this is a relatively new phenomenon, there seem to be inconsistencies between the core characteristics and elements of a business model, ultimately resulting in inconsistencies of what BMI entails. BMI is defined as the need to significantly transform the existing business model, known as the value proposition of the business (Bouwman et al., 2017). Koen et al., (2011) regards value networks, value creation and value capture as primary components of a business model. Other authors (Girotra $\&$ Netessine, 2014) suggest that the innovation process should start with identifying the risks in the value chain, opposed to Dmitriev et al., (2014) suggesting one should start with the value proposition and targeting customers. Research studies in digitalisation and digital transformation 
have increased in the past few years in academic literature; a number of prominent scholars are proposing constructs for these concepts (Li et al., 2017; Legner et al., 2017). Regardless of this, there seems to be a lack of consensus on the constructs of digitalisation, digital transformation and BMI (Bouwman et al., 2017). Moreover, the relationships between the three concepts are unclear. This gap in the literature means that businesses lack guidelines on how BMI should be pursued through digital transformation (Eksell \& Härenstam, 2017) and indicates a need to develop a framework to assist in this endeavour.

The purpose of this paper is twofold. Firstly, it identifies the constructs underlying the three concepts of Digitalisation, Digital Transformation and BMI in literature as well as the commonalities between them. Secondly, the paper improves understanding of the concepts of digital transformation and BMI by developing a framework indicating how businesses can digitally transform their business model elements, resulting in BMI. This is achieved through a map depicting the identified constructs of each concept and pinpointing any overarching themes.

\section{RESEARCH QUESTION}

The aim of this paper is to develop a conceptual model indicating how businesses can digitally transform existing business model elements resulting in Business Model Innovation. The primary research question can therefore be formulated as follows: How can businesses digitally transform existing elements within their business models through digital transformation?

The main research question is broken down into two sub-questions:
1. What are the constructs of Digitalisation, Digital Transformation and Business Model Innovation?

2. What commonalities exist between Digitalisation, Digital Transformation and Business Model Innovation?

\section{RESEARCH METHODOLOGY}

Given the research aim of this study, academic literature first needs to be identified and scrutinised. The study was conducted using a descriptive research approach through a qualitative narrative review. This is deemed a suitable method to address the type of research problem being investigated in this study (Ferrari, 2015). A narrative review allows a researcher to systematically gather, analyse and represent other authors' findings and to identify any inconsistencies in the body of knowledge. The narrative review is one of the oldest procedures, described as qualitative, non-quantitative, literary and verbal by Hunter and Schmidt (2004). Furthermore, it allows the researcher to extract the results of each of the selected studies and attempts to find an overarching theory that conforms the findings. The results of a narrative review serve as an educational tool for practitioners, providing a more updated perspective on the given topic (Green et al., 2006).

The purpose of the narrative literature review was to synthesise evidence describing constructs and conceptual models on Digitalisation, Digital Transformation and BMI. The aim was to identify the factors indicating how organisations could digitally transform elements of a traditional business model into one underpinned by innovative digital technologies. Figure 1 shows the steps which were followed to conduct the narrative review. 


\section{Journal of Contemporary Management Issues}

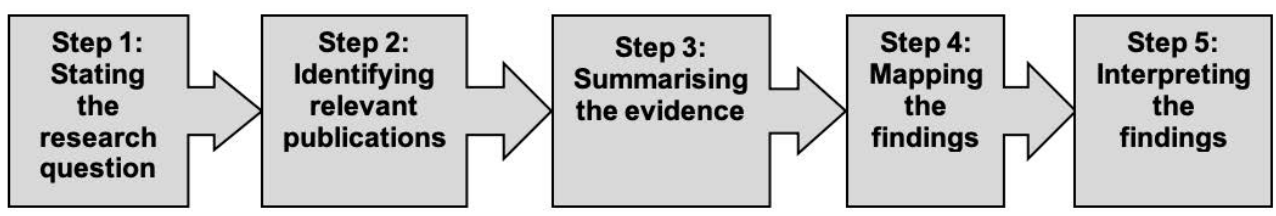

Figure 1. Visualisation of research methodology steps

The first search was conducted in October 2019, using electronic databases, such as EbscoHost, Emerald, Sage Review, Proquest and Sabinet. Keywords included 'digitalisation', 'digital transformation' and 'BMI'. The articles which were identified through this preliminary search were screened against inclusion and exclusion criteria. The criteria specified that the articles had to: (i) be full-length journal articles, (ii) written in English, (iii) empirical in nature, (iv) contain processes, theories, conceptual frameworks and systematic reviews related to the keyword searches. The preliminary search identified 243 articles which were screened against the criteria. This narrowed down the search to 158 articles. These were uploaded onto Atlas.ti to conduct the coding process in a simultaneous and iterative way.

Each article was scrutinised via the codes to identify key information, which was coded under emerging themes, using thematic analysis. During the first round, a tree of codes was created, followed by several other codes as the codification progressed. The themes that emerged in past studies were reflected as ubiquitous constructs on a map. From the multitude of initial themes, 21 key themes were identified between all the concepts, as discussed in the section 'Discussion of the relevant concepts'. An inductive approach was used for the coding. Thomas (2006:238) indicates that this type of approach is "primarily used [for] detailed readings of raw data to derive concepts, themes, or a model through interpretations made from the raw data by an evaluator or researcher". In this way, the key findings of relevant studies were thematically analysed and synthesised.

\section{LITERATURE REVIEW}

This section presents definitions of the three concepts of digitalisation, digital transformation and BMI and discusses the constructs of each, aiming to identify the overarching constructs linking all three concepts.

\subsection{Digitalisation}

The terms 'digitisation' and 'digitalisation' are often used interchangeably, however, a clear distinction exists between the two. The Gartner IT Glossary (2017:1) defines the former as "the transformation process of analogue information into digital information", while the latter is viewed as "the use of digital technologies to change a business model and provide new revenue and value-producing opportunities; it is the process of moving to a digital business". Digital technologies have advanced over the past few decades in the three waves of digitalisation which have transformed business and society. Legner et al., (2017) explains these waves using practical examples. The first wave introduced computers with the aim of reducing paper carried around by individuals and increasing automation in work routines. The second wave introduced the internet on a global scale, resulting in value creation changes of new businesses such as e-commerce. It 
is argued that the third wave is currently being experienced by businesses and society where processing power, storage capacity and communication bandwidth has increased, resulting in the ubiquitous computing becoming a reality rather than a fantasy (Legner et al., 2017). These advancements have created the need for radically new business models, with Porter and Heppelmann (2014) agreeing with this notion. Digitalisation has unlocked a new spectrum of possibilities for businesses to interact with customers, understand the needs of customers which is one of the reasons why businesses need to rethink their business models (Wirtz et al., 2010).

Digitalisation offers many benefits in a variety of ways, one of which is the better use of knowledge (Parida et al., 2015), ultimately resulting in increased productivity and efficiency (Porter \& Heppelmann 2014). It is important to note that digitalisation needs to be applied to the whole business system; it is not an 'add-on' element to a business area, or function (Mäkiö et al., 2018). To successfully adopt digital technologies, underlying digitalisation/technological capabilities are required. Moorman and Slotegraaf (1999) define technological capabilities as the necessary business skills, talent and expertise to develop and manage new products and processes. Trinh et al., (2012) agrees with this statement, by claiming that organisational agility is not only about collecting and analysing data, but moreover about the decision making and deployment of changes. Sambamurthy et al., (2003) claims that digitalisation increases an organisation's capabilities such as agility and IT capabilities, resulting in a competitive advantage.

One of the organisational effects stemming from digitalisation is the concept of organisational agility. According to Alavi et al., (2014), organisational agility is a distinct advantage and strategic imperative in today's rapidly changing business environment. It offers two key benefits: (i) to timeously respond to business threats and (ii) the ability to identify and capitalise on opportunities. Trinh et al., (2012) agrees with this statement, by claiming that organisational agility is not only about collecting and analysing data, but moreover about the decision making and deployment of changes. Sambamurthy et al., (2003) claims that digitalisation increases an organisation's capabilities such as agility and IT capabilities, resulting in a competitive advantage. Thus, it involves all aspects of the organisation's architecture which include processes, people, information, technology and strategy.

Digitalisation can also be driven by businesses through developing digital products and business models that are close to the core business. For a organisation to be product-centric, strong alignment is required between the business and the IT department in order to harmonise business and IT decisions. Thus, the dominant logic of the IT department has to be changed from a project to a product perspective with the customer firmly in mind (Urbach et al., 2019). Khin and Ho (2019) concur, stating that by transforming IT projects into digital products or solutions allows for the transformation of other traditional products and services. This can, in turn, create completely new businesses. Digitalisation is intertwined with digital transformation, which is discussed in the following section. Against this background, the following proposition is made:

\section{Proposition P1:}

Developing new or adapting existing products that are 'digitally infused' increases the chances of innovating the business model. 


\section{Journal of Contemporary Management Issues}

\subsection{Digital transformation}

Digital transformation has become a strategic imperative for businesses. Young and Rogers (2019:683) define digital transformation as "a technology-driven process of change derived from ubiquitous data, connectivity and decision making". Digital transformation not only refers to technological changes, but it also has an impact on the business itself (Hinings et al., 2018). Matt et al. (2015:339) maintain that digital transformation leads to the "transformation of key business operations and affects products and processes, as well as organizational structures and management concepts". The aim of digital transformation is to create new possibilities for the future as opposed to simple technological changes seeking to correct the mistakes of the past. Orji (2019) agrees that digital transformation is the process aimed to align the business process and cultural transformation with the changing needs of the business environment. This requires a fundamental change in decision making, specifically in how work should be executed and how information should be used. Digital technologies have created a much more volatile, complex and uncertain business environment. It is therefore crucial to understand how these technologies can bring about changes in the business model, organisational structure, processes and systems (Hess et al., 2016).

Some of the most common digital transformation goals identified in the literature seek to increase flexibility, enhance customer-centric processes and ensure cost reduction (Hofmann \& Rüsch, 2017). Corver and Elkhuizen (2014) claims that the key construct of digital transformation is the customer, thus processes must be developed in such a way that customer needs are understood by digitalising the customer experience. This will allow the business to identify the customer's purchase history through an in-depth analysis of the internet. Such an analysis can identify which complementary products the customer has purchased and determine whether any other customers have a similar purchase history. Following this, products and services need to be digitalised, by creating an experience when using the product and, if needed, adapting the product to satisfy the need of the customer (Mhlungu et al., 2019). To successfully execute the above, operations must be digitalised, such as automating and standardising processes. This will allow businesses to become more agile and more responsive to the needs of customers. Mhlungu et al., (2019) conducted a study to identify the internal success factors with relation to organisational digital transformation. The study revealed that in order for a business to succeed in digital transformation, the business constantly needs to keep abreast with customer needs, especially when designing the product or service offerings and should adopt a user-centred approach. The value chain of the business must also be digitalised, taking into consideration every single aspect of the business. Digital solutions can reconfigure the existing business ecosystem, offering new products or services, focusing on a niche market or simply adding value to the existing customer experience (Mäkiö et al., 2018). Against this background, the following proposition is made:

\section{Proposition P2:}

Identifying and understanding the needs of the twenty first century customer will require changes in customer service delivery, through digital platforms, resulting in increased customer satisfaction and better customer experience.

Considering the rapid technological advances in today's business environment, 
many businesses, in conjunction with their IT departments, have developed digital strategies. Bharadwaj et al. (2013:472) define a digital business strategy as an "organisational strategy formulated and executed by leveraging digital resources to create differential value". Moreover, digital transformation needs to be driven by individuals who possess the necessary skills. These skills are related to areas such as artificial intelligence, mobile development, data analysis, cybersecurity, cloud computing, digital strategy development and data architecture (Gottlieb \& Willmott, 2014). Jafarzadeh et al., (2015) claims that to successfully execute digital transformation, a business needs to clearly define initiatives related to a digital strategy. Gudergan and
Mugg (2017) agrees that a business digital strategy is crucial for an effective and efficient transformation process. It is, therefore, an imperative for business leaders to create a bold strategy and culture that would foster innovation in employees and encourage them to experiment with new technologies within their business models.

\subsection{Business model innovation}

Business model innovation is a wellknown concept in the business sphere as well as the literature on management science. There is, however, no consensus on a universal definition of the concept. Table 1 below gives an indication of the varied definitions in existence.

Table 1. Definitions on business model innovation

\begin{tabular}{|l|l|}
\hline Author & Definition of Business Model Innovation \\
\hline Timmers $(1998,4)$ & $\begin{array}{l}\text { "....an architecture of the product, service and information flow, including } \\
\text { a description of the various business actors and their roles; a description } \\
\text { of the potential benefits for the various business actors; a description of } \\
\text { the sources of revenues". }\end{array}$ \\
\hline $\begin{array}{l}\text { Chesbrough and Rosenbloom } \\
(2002,529)\end{array}$ & $\begin{array}{l}\text { "...the heuristic logic that connects technical potential with the } \\
\text { realization of economic value" }\end{array}$ \\
\hline $\begin{array}{l}\text { Johnson, Christensen, and } \\
\text { Kagermann }(2008,60)\end{array}$ & $\begin{array}{l}\text { "A business model, from our point of view, consists of four interlocking } \\
\text { elements that, taken together, create and deliver value. The most } \\
\text { important to get right, by far, is the first. } \\
\text { Customer value proposition ... profit formula... key resources.... }\end{array}$ \\
\hline Amit and Zott $(2015,346)$ & $\begin{array}{l}\text { "...describes how a focal organisation taps into its ecosystem to perform } \\
\text { the activities that are necessary to fulfil perceived customer needs". }\end{array}$ \\
\hline Wirtz et al., $(2016,6)$ & $\begin{array}{l}\text { "... a simplified and aggregated representation of the relevant activities of } \\
\text { a company". }\end{array}$ \\
\hline
\end{tabular}

Source: Adapted from Peric et al., (2017:3)

It is clear from the above definitions that a business model is related to the business activities of an organisation and how these activities are carried out to satisfy the needs of customers. A business model is thus a blueprint for a business to achieve efficiency, strategic objectives and value for all stakeholders (Small et al., 2015). Table 2 below indicates the constituent elements of a business model. 


\section{Journal of Contemporary Management Issues}

Table 2. Overview of business model components

\begin{tabular}{|c|c|}
\hline Author(s) & Components \\
\hline Mahadevan $(2000,59)$ & $\begin{array}{l}\text { "A business model is a unique blend of three streams that are } \\
\text { critical to the business. These include the value stream for the } \\
\text { business partners and the buyers, the revenue stream, and the } \\
\text { logistical stream." }\end{array}$ \\
\hline Voelpel, Leibold, and Tekie $(2004,40)$ & $\begin{array}{l}\text { "new customer value proposition(s); a value network } \\
\text { configuration for that value creation; and sustainable returns } \\
\text { that ensure the satisfaction of relevant stakeholders" }\end{array}$ \\
\hline Chesbrough $(2007,1)$ & $\begin{array}{l}\text { "A business model consists of two essential elements-the value } \\
\text { proposition and the operating model—each of which has three } \\
\text { sub elements, value proposition: target segment(s), product or } \\
\text { service offering, revenue model and operating model: value } \\
\text { chain, cost model and organization" }\end{array}$ \\
\hline Osterwalder and Pigneur $(2010,29)$ & $\begin{array}{l}\text { "Four integrated business model components: } \\
\text { - Your customers } \\
\text { - Your value proposition } \\
\text { - Your infrastructure } \\
\text { - Your cost/revenue structure" }\end{array}$ \\
\hline Zott and Amit $(2010,216)$ & $\begin{array}{l}\text { "...we suggest two sets of parameters that activity systems } \\
\text { designers need to consider: design elements - content, structure } \\
\text { and governance - that describe the architecture of an activity } \\
\text { system; and design themes - novelty, lock-in, complementarities } \\
\text { and efficiency - that describe the sources of the activity system's } \\
\text { value creation." }\end{array}$ \\
\hline Abdelkafi and Täuscher $(2016,76)$ & $\begin{array}{l}\text { "Recapitulating, we use a business model framework that } \\
\text { consists of three components: value proposition, value creation, } \\
\text { and value capture." }\end{array}$ \\
\hline
\end{tabular}

Source: Adapted from Peric et al., (2017:5)

From Table 2, it can be seen that the most common business model elements that have been repeatedly cited in the literature are value offering, value proposition, value creation, profit, customers, strategy, resources, processes and cost structure. Matt et al., (2015) explain that the value offering element captures the value proposition of the business that is responsible for its competitive positioning in the market. Value creation refers to how the organisation will realise the value offering by pinpointing the core competencies and resources of the business. Moreover, value creation focuses on the organisational structure, distribution channels, internal activities and the value chain. The revenue streams explains how the business generates profits in terms of the cost structure. Against this background, the following proposition is made:

\section{Proposition P3:}

Identifying and acquiring the necessary resources to incorporate digital technologies can result in the transformation of traditional business model elements.

The business model concept is a topic of ongoing debate amongst scholars; a recent addition to this topic has been the concept of BMI. This refers to the value creation and value capturing of businesses, based on the internal processes of the business and 
its relationship with external stakeholders such as customers and suppliers. In contrast to daily incremental changes within a business, BMI implies fundamental changes to the core elements of the business model (Vils et al., 2017). Thus, to successfully manage these changes within the business ecosystem, the business requires certain capabilities. Carcary et al., (2018) claims that businesses should initially rather focus on a few key and fundamental capabilities. Catlin et al., (2015) agrees with this notion by stating that "for digital success, certain capabilitiesespecially those that build foundations for other key processes and activities - are more important than others". Some of the key capabilities include the development of digital leadership skills that will allow business leaders to design and implement a transformative digital business strategy and an agile culture that consist of digital talent (Carcary et al., 2016). Against this background, the following proposition is made:

\section{Proposition P4:}

The more existing capabilities are upgraded into digital capabilities, resulting in new capabilities being developed, the greater the chance of a digital transformation output within the business model.

Mustafa (2015) claims that the set of factors affecting BMI includes value proposition, infrastructure, the revenue model and value chain elements such as products, services, marketing and sales. Furthermore, innovating a business model is the process of reconfiguring business model elements, such as internal activities, the organisational structure to determine the links between the activities and the governance to determine who is performing the activities. Teece (2018) maintains that the BMI concept can be defined as a business that creates and captures value in unique and novel ways. A business model that has been successfully executed is one that satisfies the needs, charges a premium price that customers are willing to pay for, ensures that costs are covered and enables the business to achieve a satisfactory level of profit (Teece, 2018). However, this requires changes to one or more elements of the business model, requiring one to possess the necessary capabilities. Beyond the need to develop digital capabilities, dynamic capabilities have also been frequently cited by authors in the business model innovation sphere, with Teece (2018) combining the dynamic capabilities framework with business model elements. Teece et al. (1997) defines dynamic capabilities as "the firm's ability to integrate, build, and reconfigure internal and external competences to address rapidly changing environments".

BMI can change how the business is connected to both internal and external stakeholders and how it creates value for all stakeholders (Zott \& Amit, 2010). One of the first steps in innovating the business model is to identify unmet needs in the business ecosystem and determine whether customers would be willing to pay for the product to satisfy their needs. Latifi and Bouwman (2017) point to strategy as a driver for BMI; they claim that a strategy sets guidelines when designing a business model and that continuous redesigns are needed to ensure the business reaches its goals. Thus, it can be said that a business model should operationalise the strategy of a business. The importance of strategy has also been cited as a key element of digitalisation and digital transformation (Bharadwaj et al., 2013). Against this background, the following proposition is made:

\section{Proposition P5:}

The more existing strategy is reshaped to ensure that digital transformation is the core focus of the business, the greater the chances of achieving business model innovation. 


\section{Journal of Contemporary Management Issues}

BMI in the twenty first century must include digital technologies such as the Internet of Things, referring to physical products that can sense and communicate information of their status with the environment. This data allows a business to track how its customers are using products or services. It also creates a new kind of intellectual capital for the business that can be used for future decisionmaking (Teece, 2018). Spieth and Schneider (2016) concluded that business models within the twenty first century are required to describe the business logic, identify and capitalise on opportunities and lastly commercialise new ideas and technologies. The turbulent business ecosystem that consists of digital technologies makes it time consuming for a business model to catch up and keep up to the changes. Furthermore, challenges arise such as the complexity of incorporating digital technologies within traditional business models as well as within non-digital products and services (Nylen \& Holmstrom, 2015).

\subsection{Discussion of the relevant concepts}

It is clear from the discussion above that there are distinct overlaps between digitalisation, digital transformation and BMI. This section will disclose the results of the literature search of the three concepts. This was based on the keyword selection, which included 'digitalisation', 'digital technologies', 'digital transformation', 'business models' and 'BMI'. The literature search yielded a total of 243 articles of which 83 were disregarded as they did not meet the inclusion criteria. A total of 158 articles were, therefore, selected for review and analysis, as indicated by Table 3 .

Table 3. Literature search strings

\begin{tabular}{|c|c|c|c|c|}
\hline Search string & Database & Identified & Rejected & Accepted \\
\hline \multirow[t]{6}{*}{ Digitalisation } & EBSCO & 13 & 6 & 7 \\
\hline & ProQuest & 10 & 4 & 6 \\
\hline & Emerald & 18 & 6 & 12 \\
\hline & Sabinet & 6 & 3 & 3 \\
\hline & Springer Link & 9 & 1 & 8 \\
\hline & Sub-Total & 56 & 20 & 36 \\
\hline \multirow{6}{*}{$\begin{array}{l}\text { Digital } \\
\text { Transformation }\end{array}$} & EBSCO & 22 & 8 & 14 \\
\hline & ProQuest & 21 & 5 & 16 \\
\hline & Emerald & 12 & 2 & 10 \\
\hline & Sabinet & 12 & 8 & 4 \\
\hline & Springer Link & 5 & 3 & 2 \\
\hline & Sub-Total & 72 & 26 & 46 \\
\hline \multirow[t]{7}{*}{ BMI } & EBSCO & 26 & 12 & 14 \\
\hline & ProQuest & 33 & 7 & 27 \\
\hline & Emerald & 40 & 13 & 27 \\
\hline & Sabinet & 9 & 7 & 2 \\
\hline & Springer Link & 7 & 1 & 6 \\
\hline & Sub-Total & 115 & 40 & 76 \\
\hline & Total & 243 & 86 & 158 \\
\hline
\end{tabular}


Once the 158 articles were reviewed through thematic content analysis using Atlas.ti, commonalities between the three concepts were extrapolated, as presented as a construct map by Figure 2 .

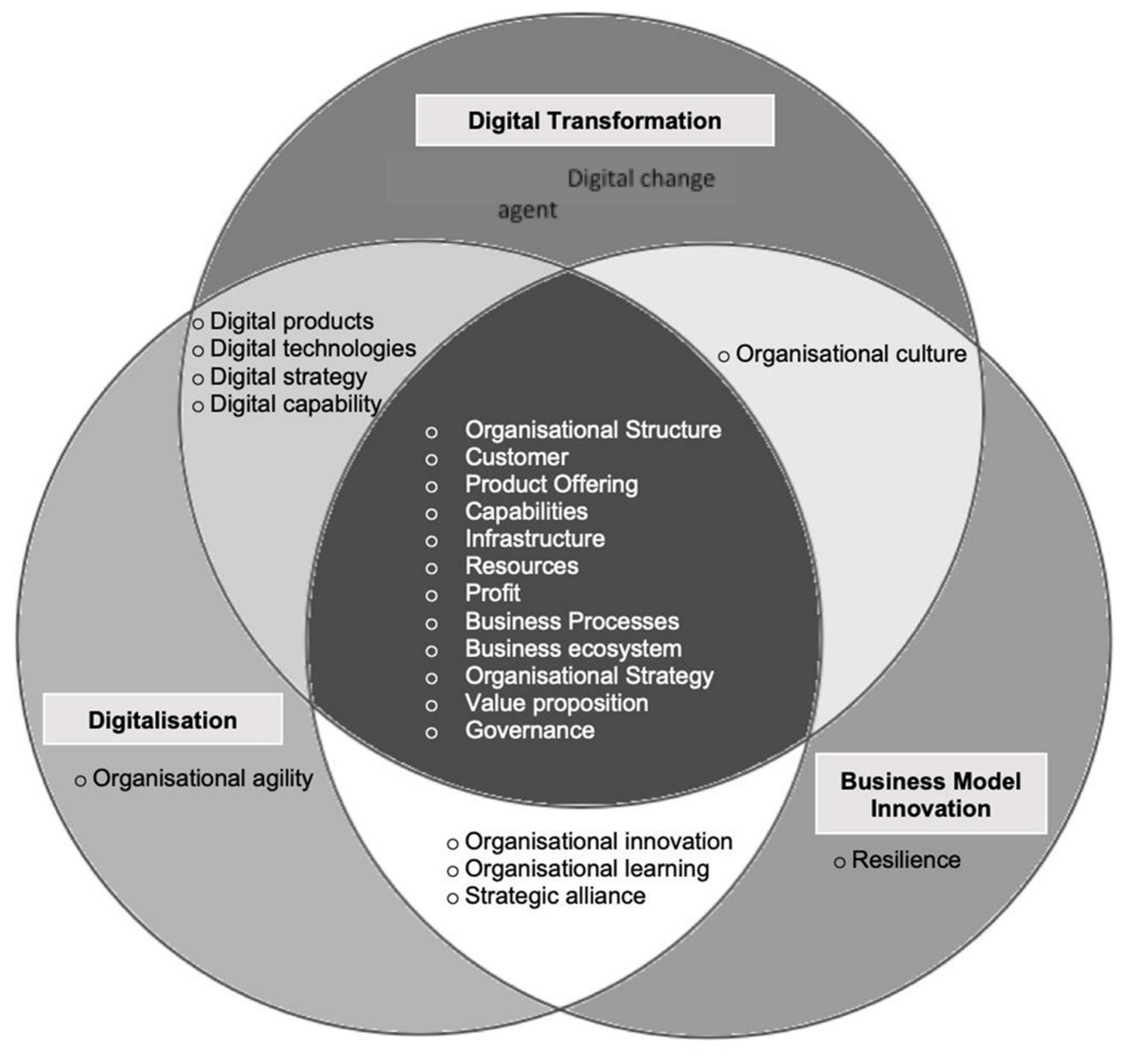

Figure 2. Construct map

Figure 2 shows that the exterior of the map contains all three concepts, each with its independent construct. The interior of each circle represents a set of constructs that overlap, showing the communalities between the concepts.

The first exterior circle at the top, Digital Transformation, represents an organisation acting as a digital change agent. The interior circle at the top left, between digital transformation and digitalisation includes four important constructs. Firstly, to ensure an efficient and effective transformation process, a digital strategy is required. Secondly, it involves the use of digital technologies, thirdly introducing digital products, which can either be fully digital or digitally 'infused' and fourthly possessing the required digital capabilities. The interior circle at the top right between digital transformation and BMI requires changes in the organisational culture to facilitate 


\section{Journal of Contemporary Management Issues}

openness, change and innovation within the technological sphere.

The second exterior circle on the left side, Digitalisation, represents the ability of an organisation to facilitate openness and flexibility when adopting digital technologies, known as organisational agility. The interior circle at the bottom left, between Digitalisation and BMI, reflects three important areas. Firstly, an organisation has to be innovative in terms of new product, service or process development/ improvement, known as organisational innovation. Secondly, the organisation must continuously create new knowledge, skills and competencies, known as organisational learning. Lastly, strategic alliance plays a critical role in all the above, requiring one to build and enhance capabilities, focusing on continuous innovation and being able to quickly respond to changes in the market.

The third exterior circle on the right side, BMI, consists of an individual independent construct that requires an organisation to quickly recover from challenges, poor decision-making and/or failures, otherwise known as resilience.

Lastly, all three concepts overlap within the middle interior circle. The organisational structure represents the way the organisation is organised and how authority is distributed, which is critical when transformational change is needed. The customer and the product offering represent the focal point of any organisation and any changes within the organisation need to be measured against customer needs and experience. To successfully use and implement digital technologies, the organisation needs to possess the necessary capabilities, infrastructure and resources that will ultimately impact profit. Moreover, the organisation will be required to make the necessary changes to its existing business processes, consider leveraging off its business ecosystem that could assist with the transformation process. The value proposition needs to be central during the transformation process, with the aim of enhancing and improving on it. Together with all of the above, if an organisation has the required governance and strategy in place, these key constructs can serve as a roadmap to successful digital transformation of the business model.

\section{FINDINGS}

The section below individually discusses the findings with regard to the three concepts of Digitalisation, Digital Transformation and Business Model Innovation.

\subsection{Digitalisation}

The search on the concept of Digitalisation identified 48 (48\%) relevant articles. Only constructs which were cited more than three times were selected, as shown in Table 4 below. Organisational agility was independently cited in seven of the digitalisation articles. It is also clear from Table 4 that four constructs overlap across two of the concepts. 
Table 4. Digitalisation and digital transformation constructs

\begin{tabular}{|l|c|c|c|c|c|c|}
\hline \multirow{2}{*}{ Constructs } & \multicolumn{4}{|c|}{ Concepts } & \multicolumn{2}{c|}{ Total } \\
\cline { 2 - 6 } & \multicolumn{2}{|c|}{ Digitalisation } & Digital Transformation & \multirow{2}{*}{ Frequency } & \multirow{2}{*}{ Percentage } \\
\cline { 2 - 6 } & Frequency & Percentage & Frequency & Percentage & & \\
\hline Digital technologies & 8 & $62 \%$ & 5 & $38 \%$ & 13 & $100 \%$ \\
\hline Digital products & 8 & $50 \%$ & 8 & $50 \%$ & 26 & $100 \%$ \\
\hline Digital strategy & 7 & $35 \%$ & 13 & $65 \%$ & 20 & $100 \%$ \\
\hline Digital capabilities & 5 & $71 \%$ & 2 & $29 \%$ & 7 & $100 \%$ \\
\hline
\end{tabular}

A traditional strategy is not sufficient to ensure digitalisation and digital transformation. Thus, a dedicated digital business strategy is needed to emphasise that digital technologies remain the core focus of achieving business goals. The importance of digital capabilities was also emphasised in the literature. With reference to the use of digital products, Carcary et al., (2016) define digital capabilities as the ability and expertise of a business to manage digital technologies for new product development.

\subsection{Digital transformation}

Thirty-nine articles were identified focusing on Digital Transformation. In Table 5 , only one construct has been identified as overlapping across two of the concepts.

Table 5. Digital transformation and BMI

\begin{tabular}{|l|c|c|c|c|c|c|}
\hline \multirow{2}{*}{ Constructs } & \multicolumn{3}{|c|}{ Concepts } & \multicolumn{2}{c|}{ Total } \\
\cline { 2 - 6 } & \multicolumn{2}{|c|}{ Digital Transformation } & \multicolumn{2}{c|}{ BMI } & \multirow{2}{*}{ Frequency } & Percentage \\
\cline { 2 - 6 } & Frequency & Percentage & Frequency & Percentage & & \\
\hline $\begin{array}{l}\text { Organisational } \\
\text { culture }\end{array}$ & 12 & $48 \%$ & 13 & $52 \%$ & 25 & $100 \%$ \\
\hline
\end{tabular}

Organisational culture was cited in 25 articles covering both digital transformation and BMI. Hock et al. (2016) claims that to radically transform a business model, internal change is required Notably, change or organisational culture, if the new dominant logic of the transformed business model is to be supported. Warner and Wäger (2019) argues that the digital transformation process requires a wide range of capabilities, such as managing, adapting/changing the organisational culture, redesigning the organisation and managing the innovation ecosystem.

\subsection{BMI}

The majority of the articles (52\%) that were identified across the various databases referred to BMI. Resilience was identified independently as an important construct, with nine articles citing the importance of being able to recover quickly after a setback. Buliga et al. (2016) corroborate this finding, claiming that BMI is an integral part of an effective business response towards changes in the environment. In Table 6 , it is clear that three constructs overlap across digitalisation and BMI. 


\section{Journal of Contemporary Management Issues}

Table 6. Digitalisation and BMI

\begin{tabular}{|l|c|c|c|c|c|c|}
\hline \multirow{2}{*}{ Constructs } & \multicolumn{4}{|c|}{ Concepts } & \multicolumn{2}{c|}{ Total } \\
\cline { 2 - 7 } & \multicolumn{2}{|c|}{ Digitalisation } & \multicolumn{2}{c|}{ BMI } & \multirow{2}{*}{ Frequency } & Percentage \\
\cline { 2 - 7 } & Frequency & Percentage & Frequency & Percentage & & \\
\hline $\begin{array}{l}\text { Organisational } \\
\text { innovation }\end{array}$ & 9 & $31 \%$ & 20 & $69 \%$ & 29 & $100 \%$ \\
\hline $\begin{array}{l}\text { Organisational } \\
\text { learning }\end{array}$ & 8 & $24 \%$ & 25 & $76 \%$ & 33 & $100 \%$ \\
\hline Strategic alliance & 2 & $20 \%$ & 8 & $80 \%$ & 10 & $100 \%$ \\
\hline
\end{tabular}

Organisational innovation was cited in 29 of the articles across both the digitalisation and BMI articles.

Teece (2010) claims that BMI is a type of organisational innovation in which organisations discover and pursue unique opportunities. In contrast, Bashir and Verma (2019) disagrees by arguing that BMI is rather seen as a new source of innovation which is different from organisational innovation. Organisational learning was cited in 33 of the articles. Salojärvi et al., (2015) found that organisational learning has a positive effect on the capability of an organisation to pursue and achieve business model innovation. Joshi et al., (2010) agrees, by stating that organisational learning contributes to organisational innovation and process effectiveness. Strategic alliance was cited in 10 of the articles. During the BMI process, organisations perform a variety of activities, such as forming strategic alliances in order to create value (Hossain, 2017). Mansour and Barandas (2017) agrees, stating that strategic alliances can assist organisations in developing an ecosystem that is centred around the customer experience and the product, especially in digitalisation driven organisations.

As shown in Table 7, twelve constructs were identified as sharing commonalities with the three concepts of Digitalisation, Digital Transformation and BMI.

Table 7. Communality constructs of digitalisation, digital transformation and BMI

\begin{tabular}{|l|c|c|c|c|c|c|c|c|}
\hline \multirow{2}{*}{ Constructs } & \multicolumn{9}{|c|}{ Concepts } & \multicolumn{2}{c|}{ Total } \\
\cline { 2 - 8 } & \multicolumn{2}{|c|}{ Digitalisation } & \multicolumn{2}{|c|}{$\begin{array}{c}\text { Digital } \\
\text { Transformation }\end{array}$} & \multicolumn{2}{c|}{ BMI } & \multirow{2}{*}{ Freq. } & \% \\
\cline { 2 - 9 } & Freq. & $\mathbf{\%}$ & Freq. & $\mathbf{\%}$ & Freq. & $\%$ & & \\
\hline $\begin{array}{l}\text { Organisational } \\
\text { structure }\end{array}$ & 11 & $18 \%$ & 17 & $27 \%$ & 34 & $55 \%$ & 62 & $100 \%$ \\
\hline Customer & 39 & $28 \%$ & 24 & $17 \%$ & 76 & $55 \%$ & 139 & $100 \%$ \\
\hline Product & 45 & $32 \%$ & 23 & $17 \%$ & 71 & $51 \%$ & 139 & $100 \%$ \\
\hline Capabilities & 38 & $30 \%$ & 20 & $16 \%$ & 69 & $54 \%$ & 127 & $100 \%$ \\
\hline Infrastructure & 27 & $34 \%$ & 16 & $20 \%$ & 36 & $46 \%$ & 79 & $100 \%$ \\
\hline Resources & 40 & $29 \%$ & 23 & $17 \%$ & 73 & $54 \%$ & 136 & $100 \%$ \\
\hline Profit & 25 & $23 \%$ & 12 & $11 \%$ & 71 & $66 \%$ & 108 & $100 \%$ \\
\hline
\end{tabular}


Management, Vol. 25, 2020, No. 2, pp. 111-132

C. Tonder, C. Schachtebeck, C. Nieuwenhuizen, B. Bossink: A FRAMEWORK FOR DIGITAL ...

\begin{tabular}{|l|c|c|c|c|c|c|c|c|}
\hline $\begin{array}{l}\text { Business } \\
\text { processes }\end{array}$ & 27 & $44 \%$ & 16 & $26 \%$ & 19 & $31 \%$ & 62 & $100 \%$ \\
\hline $\begin{array}{l}\text { Business } \\
\text { ecosystem }\end{array}$ & 9 & $38 \%$ & 5 & $21 \%$ & 10 & $42 \%$ & 24 & $100 \%$ \\
\hline $\begin{array}{l}\text { Organisational } \\
\text { strategy }\end{array}$ & 38 & $28 \%$ & 22 & $16 \%$ & 74 & $55 \%$ & 134 & $100 \%$ \\
\hline $\begin{array}{l}\text { Value } \\
\text { proposition }\end{array}$ & 14 & $15 \%$ & 13 & $14 \%$ & 65 & $71 \%$ & 92 & $100 \%$ \\
\hline Governance & 18 & $27 \%$ & 14 & $21 \%$ & 35 & $52 \%$ & 67 & $100 \%$ \\
\hline
\end{tabular}

Organisational structure, the customer and the product offering have been emphasised. As explained above, in the section on Digitalisation, digital products are seen as crucial in the digital transformation process. These products need to be adapted to include a digital element or alternatively, a new digital product must be developed altogether. Businesses need to possess the necessary capabilities, and digital capabilities in particular, to successfully execute digitalisation, digital transformation and BMI. For a business to succeed in the rapidly changing marketplace, the use of digital technologies has become crucial within more than one area of the business, infrastructure in particular becomes an important construct, requiring a business to possess the necessary resources as a lack of such resources could undermine profit.

The findings of business processes, business ecosystem and organisational strategy in Table 7 are supported by Crowley et al. (2017), who agrees that these constructs are crucial for all three concepts, stating that digital transformation requires businesses to make changes to the business models, business process, rethink their strategy and collaborate with the entire business ecosystem that will allow a business to be more innovative in terms of new product and service development that includes the use of digital technologies.
Changes within business processes can require collaboration across the entire business ecosystem. Businesses also need to rethink their business strategy to ensure it is aligned with achieving overall business goals, thus strategy is crucial within all three concepts. Matt et al. (2015) contend that value proposition is another important construct of digital transformation, as supported by $14 \%$ of the articles. Lastly, governance has been highlighted as important for all three concepts.

\section{CONCEPTUAL FRAMEWORK}

To answer the main research question of the study, a conceptual framework was constructed based on the literature search, the construct map (see Figure 2) and the research propositions. This framework indicates how organisations can digitally transform elements of their business model, resulting in BMI. This is represented in Figure 3 below. Each of the elements included in the framework has been identified as a construct common to all three concepts of Digitalisation, Digital Transformation and BMI. The framework indicates how to digitally transform the left-sided elements into the right-sided elements. The central blocks represent the action plan, indicating how this can be achieved. 


\section{Journal of Contemporary Management Issues}

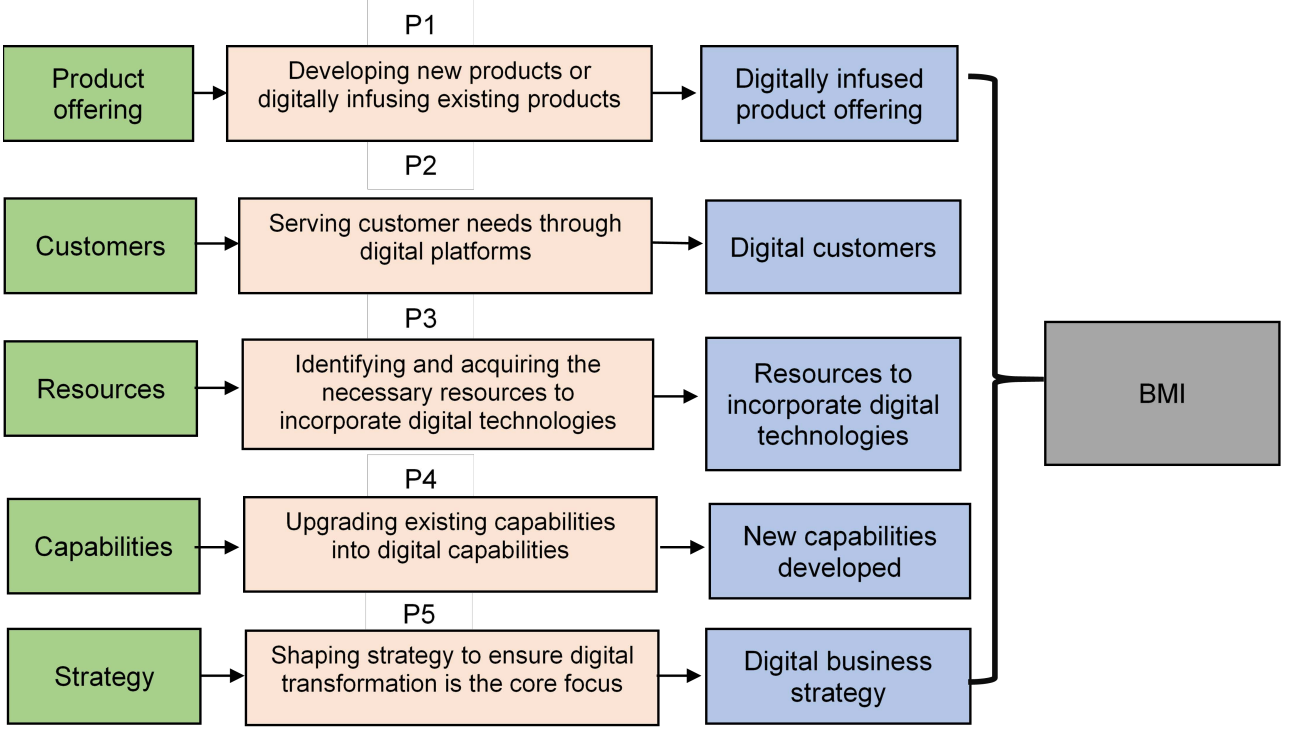

Figure 3. Conceptual framework indicating how to digitally transform elements of the business model

The following section elaborates on each area of the conceptual framework. The elements on the left side of Figure 3 are traditional elements found within a business model. As identified in the literature, to date, no clear framework exists demonstrating how these elements can be digitally transformed, resulting in BMI.

Firstly, with regard to the product offering, organisations should focus on how they could either develop new products or adapt existing ones by digitally infusing them. Secondly, the question arises of how can the customer - the main focus of any business - be better served using digital technologies, also referred to as a digital customer. Gartner (2020) defines a digital customer as someone who uses technology to buy and sell products and services. Thirdly, resources are critical in this process. This refers to the business possessing the necessary resources to incorporate digital technologies into its business model. Fourthly, the business needs to determine whether it possesses the necessary capabilities to ensure digital transformation and BMI. Alternatively, the business needs to determine whether existing capabilities can be turned into digital capabilities. This has been identified as a critical factor in terms of digitalisation and digital transformation. Lastly, the strategy needs to be adapted to include digital technologies. This is known as a digital business strategy, defined in the literature as a unique business strategy that is formulated and executed by leveraging digital technologies (Bharadwaj et al., 2013).

\section{MANAGERIAL IMPLICATIONS}

This study reviewed the key constructs of three concepts, Digitalisation, Digital Transformation and BMI in order to construct a framework indicating how organisations can digitally transform elements of their business model. The findings will provide researchers with updated constructs that have been most frequently cited in relevant literature. This will allow academic researchers to comprehend how communalities amongst the three concepts exist. The 
study has the potential to influence future research in the area of digital transformation and BMI. These two concepts can be combined as communalities exist between the concepts, thus, digital transformation can be incorporated in the process of BMI. The findings can be used as action-based recommendations to businesses and practitioners, operating in an environment of constant digital disruption. Lastly, the findings will assist businesses to alter their existing business model, with the conceptual framework acting as a point of reference, guiding business owners on how to achieve BMI through identifying potential areas to integrate digital technologies.

\section{RECOMMENDATIONS FOR FUTURE RESEARCH}

Future research should consistently explore how organisations can innovate their business models, using digital transformation in the face of the advancing Fourth Industrial Revolution. Systematic reviews could be conducted of digital transformation and BMI, in order to create a more holistic view of the two concepts. The evolution of BMI could also be investigated to determine how these constructs have been adapted to suit the business environment of the twenty first century. The research propositions, together with the conceptual framework developed as part of this study, could be tested empirically on organisations using the dynamic capability framework of Teece et al. (1997) as a theoretical lens, in conjunction with the conceptual framework developed in this study, to examine digital transformation (Warner \& Wäger, 2018) and digitalisation (Ruiz-Alba et al., 2019). Dynamic capabilities have been frequently cited by authors in the adoption process of digital technologies. Dynamic capabilities are distinct from strategy, even though they are closely connected. These capabilities are a collection of knowledge and skills that allow a business to identify new market opportunities and create a viable business model. Dynamic capabilities consider product and process development, unique managerial processes, a business culture that allows change and the ability to thoroughly scan the business environment and identify technological opportunities (Schoemaker et al., 2018). Teece (2018) has identified three broad pillars: (i) sensing is defined as knowledge production, allowing strategic decision making, (ii) seizing is the ability to develop a business ecosystem that is open for capturing an opportunity and mitigating risks and (iii) transforming is all about the continuous realignment of resources, thereby combining the dynamic capabilities framework with business model elements. The developed framework is not static and additional business model elements can be added by future researchers.

\section{CONCLUSION}

BMI is of critical importance in the business environment of the Fourth Industrial Revolution, yet such innovation is very difficult to achieve. It is therefore crucial for businesses to acknowledge the need for BMI, and particularly, the need to incorporate digital technologies into existing business models. The primary objective of this study was to develop a conceptual framework indicating how business model elements could be digitally transformed, resulting in BMI. The secondary objectives were to determine frequently utilised constructs related to Digitalisation, Digital Transformation and BMI concepts. The study validated the constructs associated with Digitalisation, namely, digital capabilities that consist of business skills and the ability to develop and manage new products 


\section{Journal of Contemporary Management Issues}

(Moorman \& Slotegraaf, 1999). The importance of a digital strategy was also emphasised. The elements of a business model were identified, including the pillars of customer-centricity, resources, processes and profit (Osterwalder \& Pigneur 2010). Based on the literature, a proposed set of propositions relating to strategy, customers, products, resources and capabilities were formulated. The commonalities between the three concepts of Digitalisation, Digital Transformation and BMI were identified as a construct map. In conclusion, a construct map was used to develop a conceptual framework demonstrating how organisations can digitally transform their business model elements, resulting in BMI. The framework focused on transforming (i) existing strategy to a digital business strategy, (ii) existing customers to digital customers, served using digital technologies, (iii) existing product offering to a digitally infused product offering, (iv) existing resources to incorporate digital technologies and (v) existing capabilities to digital capabilities. To facilitate this digital transformation to BMI, an action plan was developed in order to bridge the knowledge gap of how to digitally transform existing business model elements.

\section{References}

1. Abdelkafi, N. and Täuscher, K. 2016. "Business models for sustainability from a system dynamics perspective", Organization and Environment, 29(1), 74-96.

2. Alavi, S., Wahab, D.A., Muhamad, N. and Shirani, B.A. 2014. "Organic Structure and Organisational Learning as the Main Antecedents of Workforce Agility", International Journal of Production Research, 52(21), 6273-6295.
3. Amit, R. and Zott, C. 2015. "Crafting business architecture: The antecedents of business model design", Strategic Entrepreneurship Journal, 9(4), 331350. doi:10.1002/sej.1200

4. Bashir, M. and Verma, R., 2017. Why business model innovation is the new competitive advantage. IUP Journal of Business Strategy, 14(1), 7-13

5. Berman, S.J., Korsten, P.J. and Marshall, A. 2016. "Digital Reinvention in action - What do to and how to make it happen", IBM Institute for Business Value, 1-24

6. Bharadwaj, A., El Sawy, O.A., Pavlou, P.A. and Venkatraman, N. 2013. "Digital business strategy: Toward a next generation of insight", MIS Quarterly, 37(2), 471-482.

7. Buliga, O., Scheiner, C.W. and Voigt, K.I. 2016. "Business model innovation and organizational resilience: towards an integrated conceptual framework", Journal of Business Economics, 86(6), 647-670.

8. Catlin, T., Scanlan, J. and Willmott, P. 2015. "Raising your digital quotient”, McKinsey Quarterly, June: 1-13, available at: www.mckinsey.com/ businessfunctions/digitalmckinsey/ how-we-help-clients/digital-quotient

9. Carcary, M., Doherty, E. and Conway, G. 2016. "A dynamic capability approach to digital transformation: a focus on key foundational themes", paper presented at the European Conference on Information Systems Management, Academic Conferences International Limited, 20-28

10. Chesbrough, H., \& Rosenbloom, R. S. 2002. The role of the business model in capturing value from innovation: Evidence from Xerox Corporation's technology spin-off companies. 
Management, Vol. 25, 2020, No. 2, pp. 111-132

C. Tonder, C. Schachtebeck, C. Nieuwenhuizen, B. Bossink: A FRAMEWORK FOR DIGITAL ...

Industrial and Corporate Change, 11(3), 529-555

11. Chesbrough, H. 2007. "Business model innovation: it's not just about technology anymore", Strategy and Leadership, 35(6), 12- 17. doi: $10.1108 / 10878570710833714$

12. Corver, Q. and Elkhuizen, G. (2014), "A framework for digital business transformation", Cognizant Business Consulting Benelux .Available from: https://www.cognizant.com/ Insights Whitepapers/a-frameworkfor-digital-business-transformationcodex-1048.pdf (accessed 18 October 2019)

13. Crowley, C., Carcary, M., Doherty, E. and Conway, G. 2017. "Rethinking IT sourcing and supplier management for the digital age", paper presented at the $11^{\text {th }}$ European Conference Information Systems Management (ECISM), 64-72

14. Dewa, M.T., van der Merwe, A.F. and Matope, S. 2018. "A decision-making framework for implementing digitalisation in the South African tooling industry", South African Journal of Industrial Engineering, 29(4), 245-262.

15. Dmitriev, V., Simmons, G., Truong, Y., Palmer, M. and Schneckenberg, D. 2014. "An exploration of business model development in the commercialization of technology innovations", $R \& D$ Management, 44, 306-321.

16. Eksell, A. and Härenstam, A. 2017. "Business Model Innovation for a Digital Future", Master>s dissertation, Chalmers University of Technology, available at: https://odr.chalmers.se/bitstre am/20.500.12380/250572/1/250572.pdf (accessed 22 November 2019)
17. Ferrari, R. 2015. "Writing narrative style literature reviews", Medical Writing, 24(4), 230-235.

18. Fitzgerald, M., Kruschwitz, N., Bonnet, D. and Welch, M., 2014. Embracing digital technology: A new strategic imperative. MIT sloan management review, 55(2), 1-12

19. Gartner IT Glossary. 2017. "Digitalization and Digitisation", available at: http://www.gartner.com/itglossary/digitalization/ (accessed 14 February 2019)

20. Gartner IT Glossary. 2020. "Digital Customers", available at: https://www. gartner.com/en/information-technology/glossary/digital-customer (accessed 28 October 2020)

21. Gasparyan A.Y., Ayvazyan, L., Blackmore, H. and Kitas, G.D. 2011. "Writing a narrative biomedical review: considerations for authors, peer reviewers and editors", Rheumatology International, 31(11), 1409-1417.

22. Gottlieb, J. and Willmott, P. 2014. "The digital tipping point: McKinsey Global Survey results", McKinsey Quarterly. Available from: https://www.mckinsey.com/business-functions/mckinseydigital/our-insights/the-digital-tippingpoint-mckinsey-global-survey-results (accessed 22 November 2019)

23. Green, B.N., Johnson C.D. and Adams A. 2006. "Writing narrative literature reviews for peer-reviewed journals: secrets of the trade", Journal of Chiropractic Medicine, 5(3), 101-117

24. Girotra, K. and Netessine, S. 2014. "Four paths to business model innovation", Harvard Business Review, 92, 96-103.

25. Gudergan, G. and Mugge, P. 2017. The gap between practice and theory of digital transformation, Proceedings 


\section{Journal of Contemporary Management Issues}

in Hawaii International Conference of System Science, Hawaii, 1-15.

26. Hess, T., Benlian, A., Matt, C. and Wiesböck, F. 2016. "Options for formulating a digital transformation strategy", MIS Quarterly Executive, 5(2), 123-139.

27. Hinings, B., Gegenhuber, T. and Greenwood, R. 2018. "Digital innovation and transformation: an institutional perspective", Information and Organization, 28(1), 52-61.

28. Hock, M., Clauss, T. and Schulz, E. 2016. "The impact of organizational culture on a firm's capability to innovate the business model", Rand Management, 46(3), 433-450.

29. Hofmann, E. and Rüsch, M. 2017. "Industry 4.0 and the current status as well as future prospects on logistics", Computers in Industry, 89, 23-34.

30. Hossain, M., 2017. Business model innovation: past research, current debates, and future directions. Journal of Strategy and Management, 10(3), 342-359

31. Jafarzadeh, H., Aurum, H., D'Ambra, J., Abedin, Assemi, B. (2015). Search engine advertising adoption and utilization: An empirical investigation of inflectional factors. Organizational Computing and Electronic Commerce, 25(4), 402-427

32. Joshi, K.D., Chi, L., Datta, A. and Han, S. 2010. Changing the Competitive Landscape: Continuous Innovation through IT Enabled Knowledge Capabilities. Information Systems Research, 21(3), 472495

33. Kastalli, I.V., Van Looy, B. and Neely, A. 2013. "Steering manufacturing firms towards service business model innovation", California Management Review, 56(1), 100-123.
34. Kavadias, S., Ladas, K. and Loch, C. 2016. "The transformative business model", Harvard Business Review, 94(10), 91-98.

35. Khin, S. and Ho, T.C. 2019 "Digital technology, digital capability and organizational performance", International Journal of Innovation Science, 11(2), 177-195.

36. Latifi, S.M.A. and Bouwman, H. 2017. "Why does Business Model Innovation fail to deliver expected outcomes?" Paper presented at the International Society for Professional Innovation Management Symposium (ISPIM), ProQuest, Manchester, 1-16.

37. Mahadevan, B. 2000. "Business models for internet-based e-commerce", California Management Review, 42(4), 55-69. doi:10.2307/41166053

38. Mäkiö, J., Miroliubov, A. and Zhgun, V. 2018. "Digitalization-quo vadis?" Paper presented at the SHS Web of Conferences, 56-65. doi.org/10.1051/ shsconf $/ 20184400056$

39. Mansour, D. and Barandas, H., 2017. High-tech entrepreneurial content marketing for business model innovation. Journal of Research in Interactive Marketing, 11(3), 296-311

40. Matt, C., Hess, T. and Benlian, A. 2015. "Digital transformation strategies", Business and Information Systems Engineering, 57(5), 339-343.

41. Mhlungu, N.S., Chen, J.Y. and Alkema, P. 2019. "The underlying factors of a successful organisational digital transformation", South African Journal of Information Management, 21(1), 1-10.

42. Moorman, C. and Slotegraaf, R.J. 1999. "The contingency value of complementary capabilities in product development", Journal of Marketing Research. 36(2), 239-257. 
43. Orji, C.I. 2019. Digital business transformation: towards an integrated capability framework for digitization and business value generation. Journal of Global Business \& Technology, 15(1), 47-57

44. Nwaiwu, F. 2018. "Review and Comparison of Conceptual Frameworks on Digital Business Transformation", Journal of Competitiveness, 10(3), 86-100. https:// doi.org/10.7441/joc.2018.03.06

45. North, K., Aramburu, N. and Lorenzo, O.J., 2019. Promoting digitally enabled growth in SMEs: a framework proposal. Journal of Enterprise Information Management, 1741-0398

46. DOI 10.1108/JEIM-04-2019-0103

47. Nylén, D., and Holmström, J. 2015. Digital innovation strategy: A framework for diagnosing and improving digital product and service innovation, Business Horizons, 58(1), 57-67.

48. Osterwalder, A. and Pigneur, Y. 2010. Business model generation: a handbook for visionaries, game changers and challengers, John Wiley \& Sons, Hoboken, NJ.

49. Parida V., Sjödin D.R., Lenka S. and Wincent J. 2015. Developing global service innovation capabilities: how global manufacturers address the challenges of market heterogeneity. Res Technology Management, 58(5), 35-44

50. Peric, M., Durkin, J. and Vitezic, V. 2017. "The constructs of a business model redefined: a half-century journey", Sage Open. doi:https://doi. org/10.1177/2158244017733516

51. Porter M.E. and Heppelmann J.E. 2014. How smart, connected products are transforming competition. Harvard Business Review, 92(11), 64-88
52. Ruiz-Alba, J.L., Guesalaga, R., Ayestarán, R. and Mediano, J.M. 2019. "Interfunctional coordination: the role of digitalization", Journal of Business and Industrial Marketing, 35(3), 404-419.

53. Salojärvi, H., Tarkiainen, A., Ritala, P. and Sainio, L.M., 2015. Antecedents and consequences of business model innovation capability, paper presented the International Society for Professional Innovation Management (ISPIM), 1-18

54. Schoemaker, P.J., Heaton, S. and Teece, D., 2018. Innovation, dynamic capabilities, and leadership. California Management Review, 61(1), 15-42.

55. Small, R., Smidt, L. and Joseph, A. 2015. "The business model and due diligence: business and economy", Professional Accountant, 26, 8-9.

56. Spieth, P. and Schneider, S., 2016. Business model innovativeness: designing a formative measure for BMI. Journal of business Economics, 86(6), 671-696.

57. Teece, D.J. 2018. "Business models, business strategy and innovation", Long Range Planning, 43(2), 172-194.

58. Thomas, D.R. 2006. "A general inductive approach for analyzing qualitative evaluation data", American Journal of Evaluation, 27(2), 237-246.

59. Timmers, P. 1998. "A Business Model for Electronic Markets", Journal on Electronic Markets, 8(2), 3-8.

60. Teece, D.J., Pisano, G. and Shuen, A. 1997. "Dynamic capabilities and strategic management", Strategic Management Journal, 18(7), 509-533.

61. Urbach, N., Ahlemann, F., Böhmann, T., Drews, P., Brenner, W., Schaudel, F. and Schütte, R. 2019. "The impact of digitalization on the IT 


\title{
Journal of Contemporary Management Issues
}

department", Business and Information Systems Engineering, 61(1), 123-131.

62. Voelpel, S.C., Leibold, M. and Tekie, E.B. 2004. "The wheel of business model reinvention. How to reshape your business model to leapfrog competitors", Journal of Change Management, 4(3), 259-276.

63. Vils, L., Mazzieri, M.R., Rodrigues, G.V. and da Silva, A.R. 2017. "BMI: a bibliometric review", International Journal of Innovation, 5(3), 311-324.

64. Vuori, V., Helander, N. and Okkonen, J. 2019. Digitalization in knowledge work: the dream of enhanced performance. Cognition, Technology \& Work, 21(2), 237-252.

65. Warner, K.S.R. and Wäger, M. 2018. "Building dynamic capabilities for digital transformation: an ongoing process of strategic renewal", Long Range Planning, 52(3), 326-349.

66. Westerman, G. 2017. "Your Company Doesn't Need a Digital Strategy", MIT Sloan Management Review, 59(3), 1-6.

67. Wirtz, B.W., Pistoia, A., Ullrich, S. and Göttel, V. 2016. "Business models: origin, development and future research perspectives", Long Range Planning, 49(1), 36-54.

68. Young, A., Rogers, P. A 2019. "Review of Digital Transformation in Mining", Mining, Metallurgy \& Exploration 36, 683-699. https://doi.org/10.1007/ s42461-019-00103-w

69. Zott, C. and Amit, R. 2010. "Business model design: an activity system perspective", Long Range Planning, 43(2), 216-226.

\section{TEORIJSKI OKVIR DIGITALNE TRANSFORMACIJE I INOVACIJE POSLOVNIH MODELA}

\begin{abstract}
Sažetak
S napredovanjem koncepta četvrte industrijske revolucije, poduzeća se prilagođavaju uporabi digitalizacije, koja zahtijeva i digitalnu transformaciju postojećih poslovnih modela. Međutim, o ovom fenomenu postoji samo ograničena količina empirijskih istraživanja. Cilj ove studije je dvostruki: (i) razviti teorijski okvir za poduzeća, kako bi podvrgli svoje poslovne modele digitalnoj transformaciji te (ii) analizirati literaturu, kako bi se identificirali i utvrdili konstrukti, na kojima se temelje koncepti digitalizacije, digitalne transformacije i inovacije poslovnog modela. Studija je kvalitativne prirode $i$ temelji se na opisnom pregledu literature. Relevantni su članci identificirani korištenjem međunarodnih bibliografskih baza te su temeljito proučeni korištenjem tematske analize. Rezultati otkrivaju da prva dva konstrukta zahtijevaju digitalne sposobnosti i digitalnu strategiju. Treći konstrukt zahtijeva digitalnu transformaciju u području orijentacije prema kupcima, resursa, procesa i dobiti. Formulira se grupa istraživačkih propozicija te se mapiraju sličnosti između koncepata. Na temelju dobivene mape, razvija se konceptualni teorijski okvir. Rezultati istraživanja će biti od pomoći u razvoju budućih instrumenata, koji mogu voditi poduzeća u digitalnoj transformaciji postojećih elemenata poslovnog modela. Ovim se radom, putem izrade konceptualnog okvira, namjerava dati znanstveni doprinos u području inovacije poslovnog modela putem digitalne transformacije.
\end{abstract}

Ključne riječi: digitalizacija, digitalna transformacija, inovacija poslovnog modela 